JOURNAL OF PUBLIC HEALTH FOR TROPICAL AND COASTAL REGION (JPHTCR)

Journal homepage: http:/ejournal2.undip.ac.id/index.php/jphtr/index

ISSN : 2597-438

\title{
Contingency Plan: Comparison of Health Policies in Managing COVID-19 in Singapore and Indonesia
}

\author{
Khalish Arsy Al Khairy Siregar ${ }^{1 \star}$, Deasy Nur Chairin Hanifa ${ }^{1}$ \\ ${ }^{1}$ Faculty of Pharmacy, University Muhammadiyah of East Borneo, Samarinda, Indonesia \\ ${ }^{*}$ Corresponding Author, Email: arsysiregarr2000@gmail.com
}

\begin{abstract}
Introduction: Singapore is one of the countries with the lowest mortality rate and the best handling of COVID-19. Singapore can be an example for Indonesia on COVID 19 pandemic handling.

Methods: The method used is a literature review from google platform with these keywords: "Singapore Health Policy in COVID-19, Indonesian Health Policy in COVID-19, Singapore's success in suppressing COVID-19". The analysis was done by comparing the policies taken from the two countries in dealing with COVID-19.

Results: Singapore and Indonesia did indeed have very big differences in terms of government and in broad areas, it cannot be denied that Indonesia can have the same opportunity as Singapore in providing a good health disaster mitigation system for the community. Three factors influence Singapore's success in dealing with COVID-19: 1) having a responsive and efficient health disaster mitigation system, 2) government legitimacy which is determined by the capacity of the state. Singapore has a semi-centralized government with high legitimacy the experience of dealing with pandemics in the past, 3) Singapore's experience with SARS in the past makes Singaporeans understand very well the impact of the pandemic on their economic activities and social life.

Conclusion: Several things can be emulated from Singapore in handling COVID-19 was the transparency, strong communication between community and the government, prioritizing the benefit and safety of civil society and building obedience and awareness of COVID-19 prevention.
\end{abstract}

Keywords: COVID-19 pandemic, Contingency Plan, Health Policy, Singapore, Indonesia

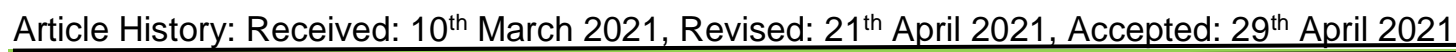




\section{Introduction}

Based on the current updated report, there was $115,967,664$ confirmed cases of COVID-19 with a worldwide death toll of $2,579,775$ people. $^{1}$ This pandemic is a threat to the whole world, a plan and emergency action are needed in determining health policies to form a safety disaster mitigation system to deal with COVID-19. Policy in health services can be viewed as an important aspect of social policy, because health is a determining factor for social welfare. ${ }^{2}$ Singapore is one of the 3 countries that have become a reference point for handling COVID-19 besides South Korea and Taiwan. Singapore has a smaller area than Indonesia, but Singapore has a high level of mobility of people, things and services, so the spread of COVID-19 is also higher. ${ }^{3}$ Based on this fact, Indonesia can learn how Singapore reduced the spread of COVID-19, and make Singapore be a role model in developing the Covid-19 Handling Policy.

Singapore is currently experiencing a severe economic recession, because its' income from industry and transit ports has decreased due to the impact of COVID-19. Singapore is very dependent on other countries. Currently, the policy in effect in Singapore prioritizes the interests of public health and safety and the economy of the Singaporean community. ${ }^{4}$

Since the beginning, Indonesia experienced delays in early handling of COVID-19 pandemic, which resulted in the first and second cases on 2 residents of Depok announced by President Joko Widodo on March 2, 2019..$^{5}$ This made Indonesia indirectly missing the preparedness for COVID-19 handling. The latest data showed that the number of COVID-19 cases in Indonesia was 1,373,836 cases, with a total mortality of 37,154 people. ${ }^{6}$ Indonesia was currently in the 4th place with the highest number of positive COVID-19 cases in Asia and was the second in the world ${ }^{7}$, which brought a bad reputation and nightmare for the Indonesians. Currently, the Indonesian government was doing its best in handling this pandemic, from persuasive ways through counseling, education on information about COVID-19, and distribution of masks to firm actions such as social sanctions and fines for violating health protocols.

Social and environmental factors influenced Indonesian society who had a low level of discipline and awareness. Nowadays Indonesian society is more focused on its economic interests. Therefore, the Government also needs to pay attention on the social and environmental conditions in formulating a policy. Indonesian government need to learn from Singapore where the economy and health go hand in hand in the time of the pandemic. The increasing number of cases and fatal impact of COVID19 in various vital sectors in Indonesia, has resulted in the need for regulations that can save Indonesia but also reduce the spread of COVID-19. The legitimacy of bureaucrats as measured by responsiveness and transparency helps in the rapid response of the pandemic. ${ }^{8}$. Comparing Singapore and Indonesian regulations can be a reference for Indonesia in formulating regulations that are right on target and have a good impact on Indonesian society.

\section{Methods}

The narrative review was used by comparing the policies taken from the two countries in dealing with COVID-19. Data were collected from articles of national and international journal publications and news using Google platform with the keywords of: "Singapore Health Policy in COVID-19, Indonesian Health Policy in COVID-19, Singapore's success in suppressing COVID-19 ". This study was conducted on February 2021.

\section{Result and Discussion}

Based on the results of the narrative reviews, we found several similarity factors between the two countries which were geographical location and in the same Southeast Asia region. On the other hand, Singapore and Indonesia have fundamental differences including the governmental system, in which Singapore has parliamentary while Indonesia has the presidential system. This 
difference leads to the discrepancy in steps of the government to decide which regulation to use, and there are also some other factors which are listed in Table 1.

\section{State Profiles of Singapore and Indonesia \\ Table 1. Brief Country Profiles of Singapore and Indonesia}

\begin{tabular}{|c|c|c|}
\hline & Singapore & Indonesia \\
\hline Area & 728 km² & $\begin{array}{c}1,905 \\
\text { million } \mathrm{km}^{2}\end{array}$ \\
\hline Population & 5.6 million & $\begin{array}{l}270,2 \\
\text { million }\end{array}$ \\
\hline $\begin{array}{c}\text { Gross } \\
\text { Domestic } \\
\text { Product }\end{array}$ & $\begin{array}{l}364,2 \text { billion } \\
\text { USD (2018) }\end{array}$ & $\begin{array}{l}1,042 \text { trillion } \\
\text { USD (2018) }\end{array}$ \\
\hline $\begin{array}{c}\text { State } \\
\text { Economic } \\
\text { Resources }\end{array}$ & $\begin{array}{l}\text { Industry, } \\
\text { tourism, } \\
\text { financial } \\
\text { services, } \\
\text { and the port } \\
\text { sector [9] }\end{array}$ & $\begin{array}{l}\text { Minerals, } \\
\text { tourism, } \\
\text { economy, } \\
\text { agriculture, } \\
\text { animal } \\
\text { husbandry, } \\
\text { creative } \\
\text { economy } \\
\text { and small } \\
\text { and } \\
\text { medium } \\
\text { business } \\
\text { traders } \\
\end{array}$ \\
\hline
\end{tabular}

The different profiles listed in Table 1 had influenced on determining a policy. Several other factors to complement the comparison of country's capacity in determining a policy, including the environmental factors of Singaporean and Indonesian society, were explored as a whole.

\section{Policies in Covid-19 Handling}

The country's capacity is determined by the Legitimacy of the Government. This country's capacity includes the ability to make decisions and the ability to access several policy alternatives. ${ }^{8}$

\section{Table 2. Data of Singapore and Indonesia on COVID-19}

\begin{tabular}{ccc}
\hline & Singapore & Indonesia \\
\hline Cases & $\begin{array}{c}60,020 \\
\text { cases }\end{array}$ & $\begin{array}{c}1,368,069 \\
\text { cases }\end{array}$ \\
\hline Mortality & 29 cases & $\begin{array}{c}37,026 \\
\text { cases }\end{array}$ \\
\hline
\end{tabular}

Source : Center For Strategic \& International Studies [10]

Based on previous research, Singapore was one of the countries assessed to have an effective system for identifying each case of the coronavirus. The Singapore Ministry of Health regularly updated the development of every new and recovered corona case through the official website. Singapore was also very active in educating the public through campaigns. They provide massive information to the public regarding simple but effective ways to prevent the spread of the virus. ${ }^{11}$

\section{SINGAPORE}

Singapore has prepared very well in facing this pandemic. This preparedness was supported by Singapore's experience from previous outbreaks, high quality of health standards, having a good network across Hospitals and health centers throughout Singapore and also immediate task force formation to deal with COVID-19. ${ }^{11,12}$

Before Covid 19 pandemic hit, Singapore had been affected by SARS and MERS outbreaks. In 2003 Singapore was overwhelmed by SARS. From these two outbreaks, Singapore had sufficient experience on how to handle the outbreaks. Currently, Singaporean Government, through the Ministry of Health, acted quickly by building Emergency Hospital and Laboratory. Singaporean government was focusing on increasing ICU capacity to anticipate the outbreak on the number of COVID-19 cases. ${ }^{11,13}$

Singaporean government communicated actively to the public using various approaches on social media. Website of: https://co.vid19.sg/singapore/clusters was 
the official website to inform the number of positive cases, as well as complete data presentation ranging from diagrams, graphs, to visual graphics and also maps of the COVID-19 spread location. ${ }^{14,15}$

Singapore is a country with a high level of discipline. Singaporean Government were seriously sanctioned the citizens who violate the regulations. Criminal offence sanctions were given to the citizens who left their homes in the isolation period. This sanction was also applied to the foreigners by depriving the right to stay in Singapore. The sanction was resulted a high level of community compliance.

\section{INDONESIA}

Indonesia experienced a delay in preparation from the start. Since the first confirmed case in China, some countries including Singapore had made early preparations to anticipate COVID-19 outbreaks. Indonesia still chose to open its doors to bring in foreign tourists which cause the lateness in anticipating COVID-19 outbreak from the start. ${ }^{16}$

When MERS and SARS entered Indonesia, previously, the anticipation was carried out by the Ministry of Health of the Republic of Indonesia directly. Monitoring was carried out at airports and international ports. Supervision to Indonesian workers who had just returned to Indonesia was also conducted. Body temperature of Indonesian and foreign tourists who visited tourist attractions or travelled were always checked and given a Health Alert Card. The management of MERS and SARS in Indonesia at that time had good supervision, which was supported by the Decree of the Minister of Health Number 424 / MENKES / SK / 2003. This decree stated that SARS is a disease that can cause an outbreak and the guidelines on handling it was added on April 3, 2003. This policy was used as a strong foundation in providing effective steps to prevent the spread of the outbreak. ${ }^{17}$ In light of the experience in MERS and SARS outbreaks handling, as well as other pandemic diseases, current health policies should reflect more on the fast and wellcoordinated surveillance. Indonesia has been ready and understood what to do during an emergency during a pandemic. Indonesia currently has COVID-19 Clustered Units from the central level to the district level. This unit includes Government official, BNPB, TNI, POLRI, and the Community who play a role in the response to COVID-19.

The Ministry of Health of the Republic of Indonesia is currently unable to be transparent in describing the number of COVID-19 cases due to the vastness of Indonesia's territory. The tracking of COVID19 patients has to be assisted by the relevant Local Government which involved the smallest level on the neighborhood (RT) and some other factors increased the difficulties. In addition, the issue of patient privacy of data dissemination also slows down the tracking of Covid-19. ${ }^{14}$ Indonesia also has an application, namely Peduli Lindungi, initiated by the Ministry of Communication and Information Technology to trace and monitor areas around the community. Using the application, by labeling each safe area, positive cases and the radius of coverage of COVID-19 patients can be informed. This application has a good impact but did not get high attention from the public. The government plays an important role in promoting and educating the community through this application. ${ }^{16}$

Indonesia has implemented PSBB, Regional Quarantine, spraying disinfectants and mask usage to break the spread of COVID-19. However, the actions taken by Indonesian officials have not provided a deterrent effect yet. In many cases, the violation to the regulation will end up on a paper with stamp duty and keep repeated. On the other hand, social sanctions will have a very good impact on society that violating health protocols can be embarrassing and 
harmed to themselves. The spread of HOAX news about COVID-19 need to be handled to reduce the spread of this HOAX news.

\section{Factors affecting Policy Economic Factors}

In the economic sector, these two countries are experiencing the same crisis. Singapore experienced a more severe crisis because the source of economy driving came from the port transit connecting services. This was exacerbated by a lot of economic activities being stopped which resulted in severe economic depression. On the other hand, despite the economic crisis conditions, Singapore remains consistent in serving and maintaining the health of civil society and immigrants. Singapore in its services provides a stimulus to 5 sectors, including 3 sectors (Households, Entrepreneurs and Fresh graduate, and Small and medium business traders). The Singapore government also gives subsidies for needed funds, business assistance, and business credit assistance. Public Services and Taxes and Credits increased the budget for health, tourism, public transportation, and also increase incentives for health workers. In the tax and credit sector, tax payments and tax subsidies for immigrant workers are carried out.

Singapore experienced a decline economy. Besides the expenditures incurred during a pandemic, the Singapore government did a risky but responsible step. This can be seen from the decision of the President of Singapore, Halim Yacob, who was willing to cut his salary voluntarily to give bonuses to health workers and other public service employees as they are the frontliners in handling COVID-19. ${ }^{18}$

In Indonesia, the Government has made efforts through economic policies including Pre-Work Cards, Community Business Fund Assistance, and various other ways to save the community's economy. However, the existing regulations have not yielded maximum results, even several existing regulations can harm the Government itself. For example, the PreWork Card Program was not running very well in reaching the main target. The main target of this program was the victims of layoffs and small and medium business actors who experienced the greatest impact. This was confirmed by the BPS findings that showed $66.5 \%$ of pre-employment card recipients are workers, $22.2 \%$ were the unemployed, and $11.3 \%$ were the non-labor force. ${ }^{19}$

The target inaccuracy of this program proved that there was a miss-communication between the community and government officials and the level of concern and community compliance was very low. Some of the community groups feel that they really need the benefits of this program, even though they are quite capable. On the other hand, some others who really need, did not get the benefit of this program. Therefore, the Indonesian government must target its programs to productive sectors such as small and medium business actors. As occurs several years ago, when Indonesia was hit by an economic crisis, the small and medium business actors were the saviors of Indonesian economy. Besides, the increased incentives for health workers, who are the front-liners in handling Covid19 pandemic are also needed.

\section{Social and Environmental Factors}

Singaporeans had used to live in a disciplined society, by obeying the law. The discipline of Singapore society was not formed instantly. Previously, the Singaporean were also difficult to obey the regulation, just like Indonesian. However, the Singapore government has a firm strategy and regulations to make the people complied to the rules.

The factors that influence a successful policy, include: 1) Public legal awareness regarding certain events is not in line with the 
awareness of legal officials, 2) Public behavior patterns have not been in line with written legal provisions especially in legal certainty and public order, 3) Legal awareness of officials has not been in line with written legal provisions. ${ }^{20}$

Indonesian community still have low awareness and discipline in obeying a policy. This is due to the burdened feeling by the regulations, even though, the regulations aimed for the sake for all. Some of Indonesian community are still thinking about the respective economic factors to save themselves. Some of them also still did not believe that the government aimed for the better condition in the future and for a wider community.

Several things can be imitated by Indonesian government in implementing a disciplined and law-abiding society. Several factors which made Singapore successful are the consistent law enforcement, important roles of technology, building public awareness, and values of life. ${ }^{21}$

\section{Conclusion}

The three factors for the success of Singapore in Covid 19 handling: 1) the responsive and efficient health disaster mitigation system, efficient and affordable health services, the use of big data and artificial intelligence in case tracing, 2) the legitimacy of the government and 3) experience in handling pandemics in the past.

Several things can be emulated from Singapore in handling COVID-19 was the transparency, building strong communication between community and the government, prioritizing the benefit of the community and the safety of civil society and building a mentality of obedience and awareness of Covid 19 prevention as well as foster a spirit of national defense.

\section{References}

1. WHO, "WHO Coronavirus Disease (COVID-19) Dashboard | WHO Coronavirus Disease (COVID-19)
2021. https://covid19.who.int/?gclid=EAlalQ obChMlyOWq7PuB7wIVDxsrCh2Mlg QNEAAYASAAEgKwOPD_BwE (accessed Feb. 24, 2021).

2. H. Sukur, Moch, B. Kurniadi, Haris, and F. N, Ray, "Penanganan Pelayanan Kesehatan Di Masa Pandemi Covid-19 Dalam Perspektif Hukum Kesehatan," J. Inicio Legis Vol. 1 Nomor 1 Oktober 2020, vol. 1, pp. 1-17, 2020.

3. C. Hennida, "Penanganan COVID-19 di Singapura - Unair News," 2020. http://news.unair.ac.id/2020/12/06/pe nanganan-covid-19-di-singapura/ (accessed Mar. 07, 2021).

4. H. Widowati, "Belajar dari Vietnam dan Singapura dalam Penanganan Virus Corona - Nasional Katadata.co.id," 2020. https://katadata.co.id/hariwidowati/be rita/5e9a470d940dc/belajar-darivietnam-dan-singapura-dalampenanganan-virus-corona (accessed Feb. 25, 2021).

5. Ihsanuddin, "Fakta Lengkap Kasus Pertama Virus Corona di Indonesia Halaman all - Kompas.com," 2020. https://nasional.kompas.com/read/20 20/03/03/06314981/fakta-lengkapkasus-pertama-virus-corona-diindonesia?page=all (accessed Feb. 25, 2021).

6. WHO, "Indonesia: WHO Coronavirus Disease (COVID-19) Dashboard I WHO Coronavirus Disease (COVID19) Dashboard." https://covid19.who.int/region/searo/c ountry/id (accessed Mar. 07, 2021).

7. T. Nurdiana, "Indonesia catat kasus corona tertinggi di Asia Tenggara, nomer 4 di Asia, no 19 dunia," 2021. https://kesehatan.kontan.co.id/news/i ndonesia-catat-kasus-coronatertinggi-di-asia-tenggara-nomer-4-diasia-no-19-dunia (accessed Feb. 25, 2021).

8. C. Hennida, "The Success of Handling COVID-19 in Singa- pore: The Case of the Migrant Worker Clus- ter and 
the Economic Recession Keberhasilan Penanganan COVID-19 di Singapura: Kasus Klaster Pekerja Migran dan Resesi Ekonomi Citra Hennida," pp. 241-256, 2020.

9. World Bank, "Profil Kota Singapura Kota Berketahanan Iklim Pedoman Dasar Pengurangan Kerentanan terhadap Bencana Public," 2007.

10. Center For Strategic \& International Studies, "Southeast Asia Covid-19 Tracker," 2021. https://www.csis.org/programs/southe ast-asia-program/southeast-asia-

covid-19-tracker-0 (accessed Feb. 24, 2021).

11. CNN Indonesia, "Melihat Keterbukaan Singapura Menghadapi Virus Corona," 2020. https://www.cnnindonesia.com/intern asional/20200313113540-106483106/melihat-keterbukaansingapura-menghadapi-virus-corona (accessed Feb. 24, 2021).

12. L. W. John, Y. Leo, and T. C. Chorh, "COVID-19 in Singapore-Current Experience Critical Global Issues That Require Attention and Action," JAMA Netw., 2020, doi: 10.1001/jama.2020.2467.

13. H. Andriyanto, "James Riady: Cara Singapura Tambah ICU Rumah Sakit Bisa Ditiru." https://www.beritasatu.com/kesehata n/632531/james-riady-carasingapura-tambah-icu-rumah-sakitbisa-ditiru (accessed Mar. 07, 2021).

14. A. Budiansyah, "Lawan Corona! Ini Bedanya Transparansi Singapura \& Indonesia."

https://www.cnbcindonesia.com/news /20200313091245-4-144564/lawancorona-ini-bedanya-transparansisingapura-indonesia (accessed Mar. 07, 2021).
15. D. Quah, "Singapore 's policy response to COVID-19," no. March, pp. 104-111, 2020.

16. “Kebijakan Publik Penanggulangan Covid-19 di Indonesia: Gagap dan Terlambat - Fakultas IImu Administrasi UI," 2020. https://fia.ui.ac.id/kebijakan-publikpenanggulangan-covid-19-diindonesia-gagap-dan-terlambat/ (accessed Apr. 28, 2021).

17. D. Murdaningsih, "Begini Cara Indonesia Saat Menangani SARS dan MERS I Republika Online." https://www.republika.co.id/berita/q6s yfa368/begini-cara-indonesia-saatmenangani-sars-dan-mers (accessed Mar. 08, 2021).

18. CNN Indonesia, "Presiden Singapura Potong Gaji demi Bonus Tim Medis Corona," 2020. https://www.cnnindonesia.com/intern asional/20200302171628-106479840/presiden-singapura-potonggaji-demi-bonus-tim-medis-corona (accessed Feb. 25, 2021).

19. P. Ramadhani, "Temuan BPS: Program Kartu Prakerja Salah Sasaran - Bisnis Liputan6.com," Nov. 27, 2020. https://www.liputan6.com/bisnis/read/ 4419163/temuan-bps-program-kartuprakerja-salah-sasaran (accessed Feb. 25, 2021).

20. A. Hermawan Usman, "Kesadaran Hukum Masyarakat Dan Pemerintah Sebagai Faktor Tegaknya Negara Hukum Di Indonesia," J. Wawasan Yuridika, vol. 30, no. 1, pp. 26-53, 2014.

21. A. Naufal, "KEBERSIHAN SEBAGAI GAYA HIDUP PENDUDUK," pp. 112, 2018. 